\title{
HUKUM MENYEGERAKAN PENYERAHAN ZAKAT HARTA DAN ZAKAT FITRAH DI SAAT PANDEMI COVID-19
}

\author{
Ronny Mahmuddin \\ Sekolah Tinggi Ilmu Islam dan Bahasa Arab (STIBA) Makassar \\ Email: ronny@stiba.ac.id \\ Irsyad Rafi \\ Sekolah Tinggi Ilmu Islam dan Bahasa Arab (STIBA) Makassar \\ Email: irsyadrafi@stiba.ac.id \\ Khaerul Aqbar \\ Sekolah Tinggi Ilmu Islam dan Bahasa Arab (STIBA) Makassar \\ Email: khaerul@stiba.ac.id

\section{Azwar Iskandar} \\ Sekolah Tinggi Ilmu Islam dan Bahasa Arab (STIBA) Makassar \\ Email: azwar@stiba.ac.id
}

\begin{tabular}{|c|c|}
\hline Keywords: & $A B S T R A C T$ \\
\hline $\begin{array}{l}\text { Zakah, Money, } \\
\text { Ta'jil, Covid-19. }\end{array}$ & $\begin{array}{l}\text { The objective of this research was to recognize the law of } \\
\text { hastening the payment of zakat on wealth and zakat al-fitr in the } \\
\text { midst of Covid-19 pandemic. This research used a descriptive } \\
\text { qualitative approach which was an attempt to understand various } \\
\text { concepts found in the research process by using content analysis } \\
\text { techniques and library research. The results of the study show } \\
\text { that: first, it is possible to immediately pay zakat on wealth on } \\
\text { condition that the ratio must be sufficient, according to a strong } \\
\text { opinion namely that is the opinion of the majority of scholars; } \\
\text { second, as for zakat al-fitr, the opinion which is a view in the } \\
\text { Shafi'i school can be a solution for the current situation that it is } \\
\text { permissible to hasten zakat al-fitr since the beginning of } \\
\text { Ramadan. But the stronger opinion is that zakat al-fitr can only } \\
\text { be paid one day or two days prior to the id according to a clear } \\
\text { argument and guidance. As for the urgency of the needs of the } \\
\text { Muslims, this does not necessarily become a reason that allows } \\
\text { the hastening of zakat al-fitr so that it becomes the only solution } \\
\text { that must be taken. However there is another solution, it is } \\
\text { enhancing the encouragement for those who have adequate } \\
\text { amount to optimize charity and alms aimed at our brothers and } \\
\text { sisters who are in need in the midst of Covid-19. }\end{array}$ \\
\hline Kata kunci: & ABSTRAK \\
\hline $\begin{array}{l}\text { Zakat, Harta, Fitrah, Ta'jil, } \\
\text { Covid-19. }\end{array}$ & $\begin{array}{l}\text { Penelitian ini bertujuan untuk mengetahui hukum menyegerakan } \\
\text { penyerahan zakat harta dan zakat fitrah di masa pandemi Covid- } \\
\text { 19. Penelitian ini menggunakan metode pendekatan kualitatif } \\
\text { deskriptif yang merupakan upaya memahami berbagai konsep }\end{array}$ \\
\hline
\end{tabular}

Ronny M., Irsyad R., Khaerul A., Azwar I. Hukum Menyegerakan Penyerahan... 
yang ditemukan dalam proses penelitian, dengan menggunakan teknik content analysis (analisis isi) dan riset kepustakaan (library research). Hasil penelitian menunjukan bahwa: pertama, boleh menyegerakan penyerahan zakat harta dengan syarat harus cukup nisabnya menurut pendapat yang kuat (rajih), yaitu pendapat jumhur ulama; kedua, adapun zakat fitrah, pendapat yang merupakan pegangan dalam mazhab Syafi'i bisa menjadi solusi untuk kondisi sekarang ini, yakni bolehnya menyegerakan zakat fitrah sejak awal Ramadan. Namun, pendapat yang lebih kuat adalah zakat fitrah hanya boleh ditunaikan sehari atau dua hari sebelum hari raya berdasarkan dalil serta tuntunan yang jelas. Adapun perihal mendesaknya kebutuhan kaum muslimin, tidak serta merta menjadi alasan yang membolehkan ta'jil zakat fitrah. Sehingga ia menjadi satu satunya solusi yang mesti ditempuh. Namun, ada solusi yang lain, yaitu dengan menggencarkan anjuran kepada masyarakat yang berada (memiliki kelapangan harta) untuk lebih memaksimalkan infak dan sedekah yang ditujukan kepada saudara-saudara kita kaum muslimin yang membutuhkan di masa covid-19.

\section{PENDAHULUAN}

Akhir-akhir ini kaum muslimin di Indonesia sedang dilanda musibah besar yaitu menyebarnya virus corona (covid-19) sehingga banyak masyarakat yang terkena imbasnya. Dari segi ekonomi misalnya, masyarakat kecil terkena efek dari pembatasan sosial demi mencegah penyebaran virus ini. Sebagian harus terputus mata pencahariannya, terlebih lagi bagi yang sebelumnya memiliki kondisi ekonomi yang memprihatinkan. Mereka tentu sangat membutuhkan bantuan berupa materi untuk menopang kelangsungan hidup mereka. Oleh karena itu, mereka sangat membutuhkan bantuan materi dari orang-orang kaya untuk menopang kehidupan mereka khusunya di saat pandemi ini.

Berangkat dari hal tersebut, timbul pertanyaan tentang boleh tidaknya mempercepat pembayaran zakat harta kepada fakir miskin yang sangat membutuhkan pada kondisi pandemi ini karena melihat maslahat yang lebih besar. Meskipun hukum asal bahwa zakat harta wajib dikeluarkan jika sudah cukup nisab dan genap setahun (haulnya). Begitupula, zakat fitrah merupakan syariat dan ibadah yang sifatnya wajib dalam Islam. Setiap muslim menunaikannya di akhir Ramadan berupa satu sha' makanan dalam rangka menampakkan rasa syukur kepada Allah Ta'ala atas nikmat berbuka dan keberhasilan hamba menyempurnakan ibadah puasa Ramadan. Penyegeraan atas penunaian zakat fitrah dipandang bisa menjadi sebuah solusi. Terutama 
menjelang datangnya bulan Ramadan yang erat kaitannya dengan pelaksanaan ibadah ini. Pertanyaan yang muncul kemudian, bagaimana hukum ta'jil (mempercepat) pembayaran zakat fitrah khusus di masa pandemi covid-19 ini? Oleh karenanya, penelitian ini bertujuan untuk mengetahui hukum menyegerakan penyerahan zakat harta dan zakat fitrah di masa pandemi covid-19.

Penelitian ini menggunakan metode pendekatan kualitatif deskriptif yang merupakan upaya memahami berbagai konsep yang ditemukan dalam proses penelitian, dengan menggunakan teknik content analysis (analisis isi) dan riset kepustakaan (library research). Teknik content analysis merupakan metode penelitian yang digunakan untuk mengetahui simpulan dari sebuah manuskrip/teks. Atau dengan kata lain, analisis isi merupakan metode penelitian yang ingin mengungkap gagasan penulis yang termanifestasi maupun yang laten. Sedangkan riset kepustakaan (library research) pada penelitian ini menggunakan jenis dan sumber data sekunder yang diperoleh dari hasil penelitian, artikel dan buku-buku referensi yang membahas topik yang berkaitan dengan tema penelitian. ${ }^{1}$

\section{PEMBAHASAN}

\section{Hukum Penyegeraan Pembayaran Zakat Harta}

Penulis akan memaparkan beberapa pandangan ulama berkaitan dengan penyegeraan pembayaran zakat harta, untuk menjadi solusi terhadap bagi kaum muslimin yang masih kabur tentang masalah ini.

Menyegerakan pembayaran zakat harta seperti uang, emas dan perak serta barang dagangan, sebelum masuk haulnya (sebelum cukup setahun), maka dibolehkan menurut jumhur ulama. Hujah jumhur dalam masalah ini adalah hadis yang dihasankan oleh Syekh al-Albani bahwa Nabi shallallahu 'alaihi wasallam mengizinkan Abbas bin Abdul Muththalib (paman nabi shallallahu 'alaihi wasallam) untuk menyegarakan pembayaran zakat harta dua tahun lebih awal dari haulnya. Pendapat jumhur ulama tentang kebolehan menyegerakan pembayaran zakat harta sebelum masuk haulnya berdasarkan hadis yang sahih, juga berdasarkan penguat bahwa haul sebagaimana yang dikatakan al-Khattabi bahwa disyaratkannya masuknya haul (genap setahun) hanyalah untuk meringankan bagi orang yang terkena wajib zakat harta, maka jika ia

${ }^{1}$ Azwar Iskandar dan Khaerul Aqbar, Kedudukan Ilmu Ekonomi Islam di Antara Ilmu Ekonomi dan Fikih Muamalah: Analisis Problematika Epistemologis, Nukhbatul 'Ulum: Jurnal Bidang Kajian Islam, Vol. 5, No. 2 (2019), h. 88-105. https://journal.stiba.ac.id/index.php/nukhbah/article/view/77. 
mengugurkan haknya (haulnya), maka gugurlah haknya (haulnya). Akan tetapi, tidak sepantasnya menyegerakan pembayaran zakat hartanya lebih dari dua tahun berdasarkan zhahir-nya hadis nabi shallallahu 'alaihi wasallam. ${ }^{2}$

Ibn Rusyd ${ }^{3}$ menyebutkan bahwa Imam Abu Hanifah dan Imam Syafi' $i$ membolehkan mengeluarkan zakat harta sebelum haulnya, berdasarkan hadis yang berbunyi:

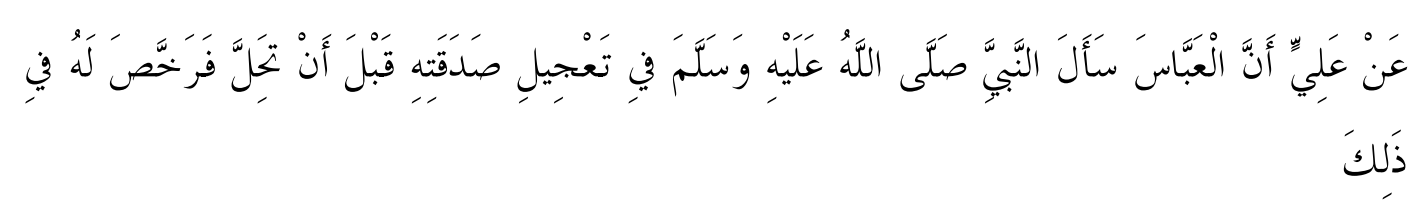

Artinya:

"Dari Ali radhiyallahu 'anhu bahwa Abbas radhiyallahu 'anhu bertanya kepada Nabi shallallahu 'alaihi wasallam mengenai menyegerakan zakat sebelum datang waktu wajib atas mereka? Lalu beliau memberikan rukhsah baginya dalam hal tersebut."

Syekh Shalih al-Fauzan juga mengatakan:

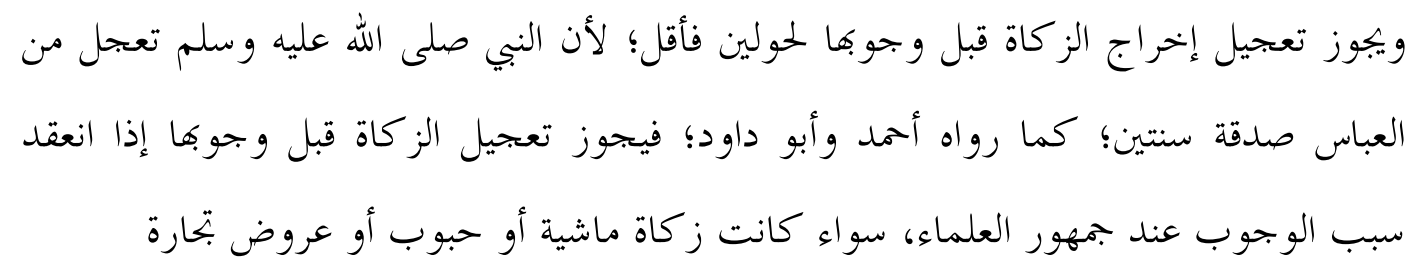

Artinya:

"Dibolehkan mengeluarkan zakat harta dua tahun lebih awal atau kurang dari itu sebelum genap haulnya sebagaimana hadis nabi shallallahu 'alaihi wasallam, bahwa nabi shallallahu 'alaihi wasallam menerima zakat harta Abbas radhiyallahu 'anhu untuk 2 (dua) tahun lebih awal dari waktunya (haulnya) sebagaimana yang diriwayatkan oleh Imam Ahmad dan Abu Dawud. Ini adalah pendapat jumhur ulama tentang kebolehan menyegerakan pembayaran zakat harta jika telah cukup nisabnya, baik

\footnotetext{
${ }^{2}$ IslamWeb.net, "Hukmu Ikhraj Ba'dhi Zakah Qabla Hulul Haul", Situs Resmi Islam Web. https://www.islamweb.net/ar/fatwa/113457

${ }^{3}$ Ibnu Rusyd, Bidayah al-Mujtahid wa Nihayah al-Muqtasid, Juz 2 (Beirut: Dar Ibnu Hazm, 1995), h. 538.

${ }^{4}$ Sulaiman al-Asy'ats, Sunan Abi Daud, Juz 2 (Beirut: Dar Ibnu Hazm, 1997), h. 188. (Hadis no. 1624, lihat juga HR. Tirmidzi no. 614, dan Ibnu Majah no. 1785).
}

Ronny M., Irsyad R., Khaerul A., Azwar I. Hukum Menyegerakan Penyerahan... 
zakat perternakan, pertanian, uang, emas dan perak atau barang dagangan." 5

Imam Ibn Baz rahimahullah (seorang ulama besar Saudi Arabia) mengatakan:

$$
\begin{aligned}
& \text { تعجيل الزكاة لا بأس به، تعجيل الز كاة للمصلحة لا بأس، فإذا كان الحول يتم في شوال وأحب } \\
& \text { المسلم أن يخرج الزكاة في رمضان فلا حرج في ذلك، لأجل فضل رمضان، أو صادف فقراء } \\
& \text { حاجتهم شديدة قبل تمام الحول فعجل لهم الز كاة. }
\end{aligned}
$$

Artinya:

"Tidak mengapa menyegerakan pembayaran zakat harta sebelum cukup setahun (haulnya). Menyegerakan pembayaran zakat harta karena ada maslahat, maka tidak mengapa. Jika haulnya baru genap di bulan Syawal, namun seseorang ingin mengeluarkan zakat hartanya di bulan Ramadan, maka tidak mengapa karena ingin mendapatkan kemuliaan bulan Ramadan atau ia melihat kondisi fakir miskin yang sangat membutuhkan sebelum cukup setahun, maka ia menyegerakan pembayaran zakat untuk mereka (fakir dan miskin)."6

Dibolehkan pula menyegerakan pembayaran zakat harta sebelum genap setahun dan setelah cukup nisabnya, apatah lagi jika menyegerakannya karena melihat kemaslahatan bagi orang-orang fakir dan miskin, sebagaimana hadis nabi shallallahu 'alaihi wasallam yang diriwayatkan oleh Ali radhiyallahu 'anhu bahwa Abbas radhiyallahu 'anhu (paman nabi shallallahu 'alaihi wasallam) pernah bertanya kepada nabi shallallahu 'alaihi wasallam tentang menyegerakan pembayaran zakat harta sebelum genap setahun, maka nabi shallallahu 'alaihi wasallam membolehkannya." 7

Contoh aplikasi menyegerakan pembayaran zakat harta sebelum genap haulnya (setahun) sebagai berikut: seseorang yang mempunyai simpanan uang yang sudah cukup nisabnya (kadarnya) senilai 85 gram emas di bulan Muharam tahun $1441 \mathrm{H}$, maka ia boleh menyegerakan pembayaran zakat hartanya sebesar

\footnotetext{
${ }^{5}$ Shalih al-Fauzan, Al-Mulakhkhas al-Fiqhi, Juz 1 (Iskandariah: Dar al-Aqidah, 2009), h. 260.

${ }^{6}$ Bin Baz, "Hukmu Ta'jil Zakah wa Miqdaruha fil Mal wa Hukmu Ikhrajiha min gairil mal allazi wajabat fihi zakah" Situs Resmi Syekh Bin Baz. https://binbaz.org.sa/fatwas/11229

${ }^{7}$ Al-Ifta al-Urdun, Yajuzu Ta'jil Zakah bi Syurut, Situs Resmi Ifta Yordania, http://aliftaa.jo/Question.aspx?QuestionId=2974
}

Ronny M., Irsyad R., Khaerul A., Azwar I. Hukum Menyegerakan Penyerahan... 
2,5\% kepada fakir miskin di bulan Ramadan tahun ini $1441 \mathrm{H}$. Sebenarnya ia berkewajiban mengeluarkan zakat hartanya jika cukup nisabnya di bulan Muharam tahun depan $1442 \mathrm{H}$ jika sudah cukup haulnya (setahun), namun ia ingin menyegerakan pembayaran zakatnya ke fakir miskin khususnya tatkala fakir miskin tersebut sangat membutuhkan bantuan, maka ini dibolehkan. Apatah lagi di saat pandemi wabah covid-19, yang mana banyak orang-orang yang sangat butuh bantuan, utamanya kaum fakir miskin.

\section{Hukum Penyegeraan Pembayaran Zakat Fitrah}

Sebelum menjelaskan hukumnya secara mendalam, perlu diketahui bahwa sedikitnya ada tiga catatan penting yang perlu diketahui perihal waktu penunaian zakat fitrah:

Pertama, waktu wajib mengeluarkan zakat fitrah adalah ketika terbenamnya matahari pada malam hari raya Idulfitri. Hal ini lantaran waktu Magrib merupakan pergantian hari dalam penanggalan Islam, maka pada waktu tersebut kaum muslimin telah wajib menunaikannya.

Kedua, waktu yang paling afdal untuk mengeluarkan zakat fitrah adalah setelah terbit fajar sebelum salat Idulfitri berlangsung. Berdasarkan hadis Ibnu Umar radhiyallahu 'anhuma:

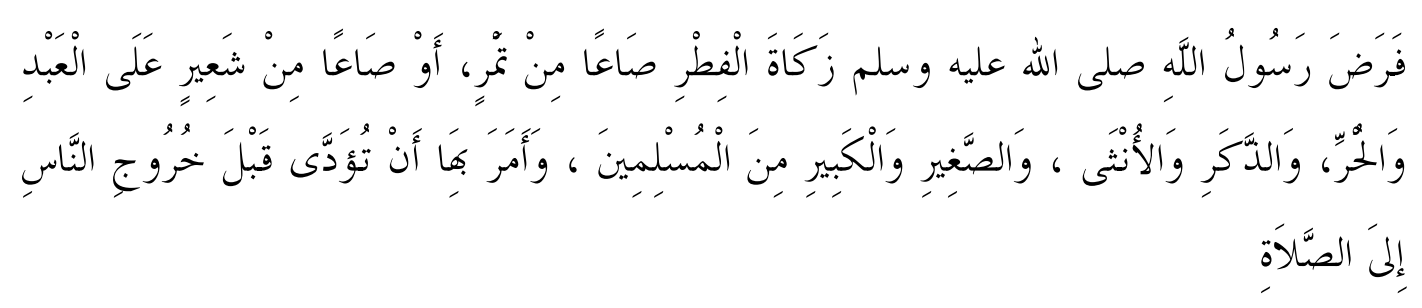

Artinya:

"Rasulullah shallallahu 'alaihi wasallam mewajibkan zakat fitrah satu sha' kurma, atau gandum, wajib bagi seluruh kaum muslimin, baik budak atau orang merdeka, lelaki atau wanita, anak-anak maupun orang dewasa. Beliau perintahkan untuk ditunaikan sebelum manusia keluar menuju tempat salat (Id)." 8

Demikian pula hadis yang diriwayatkan oleh Ibnu Abbas radhiyallahu 'anhuma, ia berkata:

${ }^{8}$ Muhammad bin Ismail al-Bukhari, al-Jami' al-Shahih, Juz. 1 (Kairo: al-Mat'ba'ah alSalafiyah, 1400H), h. 466. (Hadis no. 1503, lihat juga HR. Muslim no. 984).

Ronny M., Irsyad R., Khaerul A., Azwar I. Hukum Menyegerakan Penyerahan... 


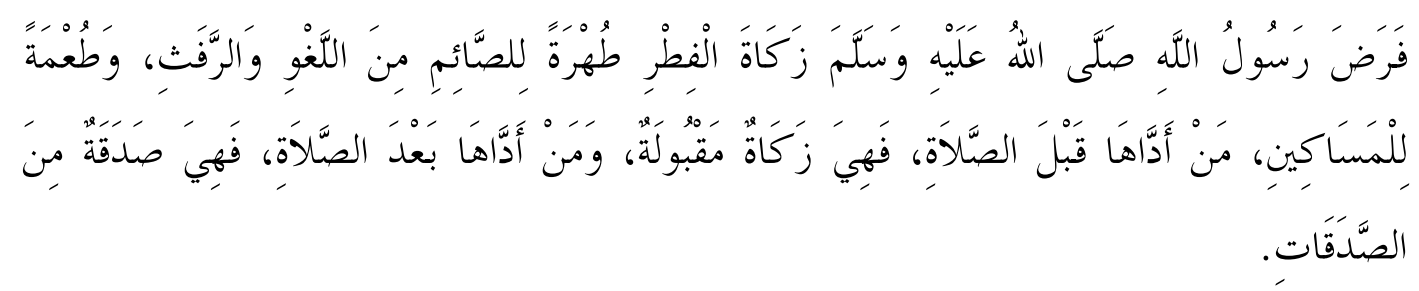

Artinya:

"Rasulullah shallallahu 'alaihi wasallam mewajibkan zakat fitrah untuk menyucikan orang yang telah berpuasa dari perkataan yang sia-sia dan kata-kata kotor, juga untuk memberi makan pada orang miskin. Barang siapa yang menunaikannya sebelum salat Id, maka zakat tersebut diterima. Barang siapa menunaikannya sesudah salat, maka ia hanyalah dianggap sebagai sedekah biasa."

Ketiga, waktu yang boleh untuk mengeluarkan zakat fitrah. Setidaknya ada 4 (empat) pendapat ulama mengenai kapan zakat fitrah boleh ditunaikan:

1) Zakat fitrah tidak boleh ditunaikan kecuali setelah masuk waktu Subuh di tanggal satu Syawal. Ini merupakan pendapat Ibnu Hazm yang disebutkan dalam al-Muhalla. Bahkan beliau menilai, jika ada orang yang menunaikan zakat fitrah sebelum waktu itu, maka zakat fitrahnya tidak sah, dan harus diulang. Beliau juga mengatakan:

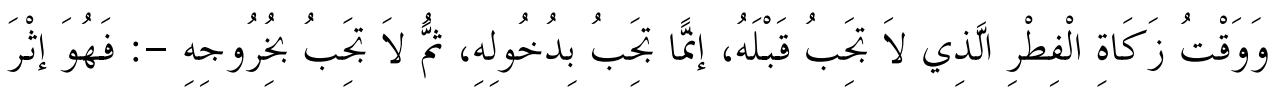

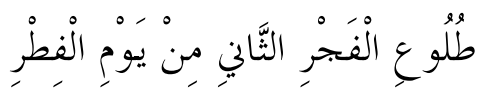

Artinya:

"Waktu zakat fitrah yang menjadi batas wajibnya seseorang menunaikan zakat fitrah adalah setelah terbit fajar subuh di hari Idulfitri." 10

Selanjutnya, beliau menegaskan:

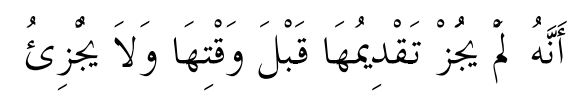

${ }^{9}$ Sulaiman al-Asy'ats, Sunan Abi Daud, Juz 2 (Beirut: Dar Ibnu Hazm, 1997), h. 179. (Hadis no. 1609, lihat juga Ibnu HR. Majah no. 1827, dan disahihkan oleh Hakim no. 1488).

${ }^{10} \mathrm{Ibnu}$ Hazm, Al-Muhalla, Juz 6, (Mesir: Idarah Al-Tiba'ah Al-Muniriyyah, 1349 H), h. 142.

Ronny M., Irsyad R., Khaerul A., Azwar I. Hukum Menyegerakan Penyerahan... 
Artinya:

"Tidak boleh menunaikan zakat fitrah sebelum waktunya dan tidak sah."11

2) Zakat fitrah boleh ditunaikan sebelum Ramadan, ini merupakan pendapat mazhab Hanafi. Al-Kasani, seorang ulama Hanafi menukil satu riwayat dari Abu Hanifah:

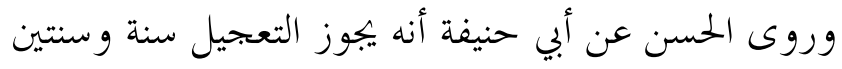

Artinya:

"Al-Hasan meriwayatkan dari Abu Hanifah bahwa boleh menyegerakan pembayaran zakat fitrah setahun atau dua tahun sebelumnya." 12

3) Zakat fitrah boleh ditunaikan sejak awal Ramadan, namun dianjurkan untuk ditunaikan sebelum berangkat salat Id. Ini merupakan pendapat mayoritas ulama mazhab Syafi'i. Al-Syirazi dalam al-Muhadzdzab mengatakan:

$$
\text { ومنه فإذا وجد تقديم الفطرة من أول شهر رمضان لأها بحب بسببين: صوم شهر رمضان والفطر جاز }
$$

Artinya:

"Boleh mendahulukan pembayaran zakat fitrah dari awal Ramadan. Karena zakat fitrah merupakan kewajiban dengan dua sebab: puasa Ramadan dan Idulfitri. Jika salah satu dari dua sebab ini sudah ada, boleh didahulukan zakat fitrah. Sebagaimana zakat mal, boleh dibayar setelah cukup nisab, meskipun belum tiba haul."13

4) Zakat fitrah boleh ditunaikan sehari atau dua hari sebelum Id. Ini merupakan pendapat dalam mazhab Maliki dan Hambali. Hal ini sebagaimana yang diriwayatkan oleh Nafi' rahimahullah:

${ }^{11}$ Ibnu Hazm, Al-Muhalla, Juz 6, h. 143.

'12 Al-Kasani, Badāi' al-Sanāi’ fi Tartib al-Syarāi', Juz 2, (Beirut: Dar Kutub Ilmiyah, 1986), h. 74.

${ }^{13}$ Asy-Syirazi, al-Muhadzdab fi Fiqh Imam Syafi'i, Juz 1, (Damaskus: Dar al-Qalam, 1992), h. 541. 


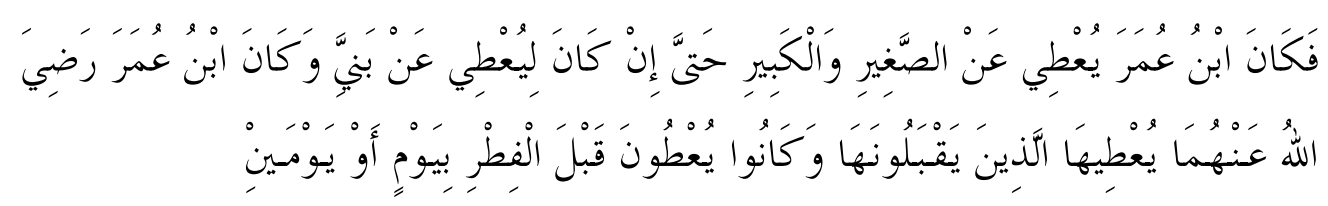

Artinya:

"Ibnu Umar radhiyallahu 'anhuma membayarkan zakat fitrah untuk anak-anak dan orang dewasa, dan beliau juga membayarkan zakat fitrah anak-anakku, dan kemudian beliau radhiyallahu 'anhuma memberikan kepada yang berhak menerimanya. Dan mereka (para sahabat) membayar zakat fitrah itu sehari atau dua hari sebelum Id."14

Berdasarkan riwayat ini, disimpulkan bolehnya mempercepat penunaian zakat fitrah sehari atau dua hari sebelum hari Idul Fitri.

Maka berdasarkan penjelasan di atas terdapat beberapa catatan dan simpulan. Atsar Ibnu Umar yang diriwayatkan oleh Nafi' ini selain menunjukkan bolehnya mempercepat penunaian zakat fitrah sehari atau dua hari sebelum hari Idulfitri, juga sekaligus menjadi sanggahan atas pendapat pertama.

Adapun pendapat kedua, merupakan pendapat yang tak berdalil. Juga karena zakat fitrah sebabnya adalah puasa Ramadan dan hari raya. Sebagaimana keterangan Ibnu Abbas radhiyallahu 'anhuma:

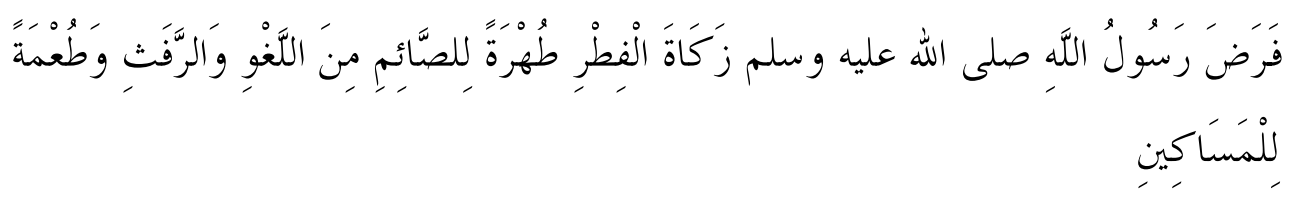

Artinya:

"Rasulullah shallallahu 'alaihi wasallam mewajibkan zakat fitrah sebagai penyuci bagi orang yang puasa dari segala tindakan sia-sia dan ucapan jorok, dan bekal makanan bagi orang miskin."15

${ }^{14}$ Muhammad bin Ismail al-Bukhari, al-Jami' al-Shahih, Juz. 1 (Kairo: al-Mat'ba'ah alSalafiyah, 1400H), h. 468. (Hadis no. 1511).

${ }^{15}$ Sulaiman al-Asy'ats, Sunan Abi Daud, Juz 2 (Beirut: Dar Ibnu Hazm, 1997), h. 179. (Hadis no. 1609).

Ronny M., Irsyad R., Khaerul A., Azwar I. Hukum Menyegerakan Penyerahan... 
Dan hikmah ini, yakni membersihkan orang yang berpuasa dari kesalahan selama puasa, serta bekal makanan bagi orang miskin ketika hari raya, tidak akan terwujud jika zakat itu ditunaikan jauh sebelum Ramadan.

Tersisa pendapat ketiga dan keempat. Namun, yang lebih mendekati kebenaran adalah pendapat yang keempat, selain karena didukung dengan atsar yang jelas (atsar Ibnu Umar dari Nafi'), juga beberapa alasan berikut:

1) Zakat fitrah, dari segi penamaan yang dinisbatkan berdasarkan waktu, artinya zakat yang dikeluarkan di waktu fitri yakni hari raya Idulfitri. Seperti salat lima waktu yang dinisbatkan kepada waktunya, begitupula puasa Ramadan yang dinisbatkan kepada bulan Ramadan. Ibnu Qudamah rahimahullah mengatakan:

$$
\text { سبب وجو بها الفطر، بدليل إضافتها إليه }
$$

Artinya:

"Sebab wajibnya zakat fitri adalah masuknya waktu fitri. Dengan dalil, penamaannya 'zakat fitri'."16

2) Telah disebutkan bahwa zakat fitrah berkaitan dengan waktu fitri (Idulfitri), maka tidak semestinya diserahkan jauh-jauh hari sebelum hari Idulfitri. Selain itu, zakat fitrah ditunaikan untuk memenuhi kebutuhan orang miskin agar mereka bisa bergembira di hari Idulfitri, sebagaimana yang diriwayatkan oleh Nafi', dari Ibnu Umar, ia berkata: Rasulullah shallallahu 'alaihi wasallam dahulu memerintahkan untuk menunaikan zakat fitrah di hari Idulfitri di mana beliau bersabda:

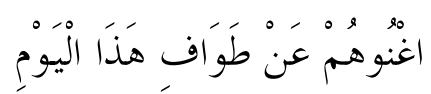

Artinya:

"Cukupilah mereka (fakir miskin) dari meminta-minta pada hari ini (Idul Fitri)."17

${ }^{16}$ Ibnu Qudamah, Al-Mugni, Juz 4, (Riyadh: Dar Alam Kutub, 1997), h. 301.

${ }^{17}$ Ali bin Umar al-Daraquthni, Sunan al-Daraquthni, Juz 3 (Beirut: Muassasah al-Risalah, 2004), h. 86. (Hadis no. 2133, lihat juga al-Baihaqi dalam al-Sunan al-Kubra no. 7739). 


\section{KESIMPULAN}

Berdasarkan pemaparan di atas, dapat dsimpulkan bahwa:

Pertama, boleh menyegerakan penyerahan zakat harta seperti zakat uang, emas dan perak, atau barang dagangan sebelum genap setahun (haulnya) namun harus cukup nisabnya, yaitu senilai 85 gram emas, dan dikeluarkan zakatnya sebesar 2,5\%. Ini adalah pendapat yang kuat (rajih), yaitu pendapat jumhur ulama. Wallahu a'lam.

Kedua, perintah mencukupi fakir miskin di sini adalah bermakna wajib. Jika zakat fitrah tersebut ditunaikan jauh-jauh hari, maka tentu maksud untuk mencukupi orang miskin pada hari raya Idul Fitri tidak terpenuhi. Adapun jika ingin ditunaikan lebih awal, maka sebaiknya ditunaikan dua atau tiga hari sebelum hari Id sebagaimana atsar Ibnu Umar yang telah disebutkan. Pendapatpendapat yang telah disebutkan tadi, yakni berkaitan dengan masalah waktu bolehnya mengeluarkan zakat fitrah, tentu telah lama menjadi pembahasan para ulama, yakni lebih tepatnya dalam kondisi normal.

Kembali pada kebijakan pemerintah ihwal pencegahan penyebaran covid19 hari ini dalam mana diterapkan social distancing, pembatasan sosial berskala besar (PSBB), lock down, dan seterusnya, maka sudah barangtentu kondisi sebagian kaum muslimin pada hari berimbas pada persoalan ekonomi, yang tentunya mereka sangat membutuhkan. Dengan demikian, adalah pendapat ketiga yang merupakan pegangan dalam mazhab Syafi'i bisa menjadi solusi untuk kondisi sekarang ini. Namun, menurut hemat penulis, pendapat yang tetap menjadi pegangan adalah pendapat keempat yang telah dipaparkan perihal kekuatan hujahnya. Alasannya bahwa zakat fitrah merupakan sebuah ibadah yang telah jelas tunt unannya, dan tentu ibadah harus berdasar dalil yang jelas.

Adapun perihal mendesaknya kebutuhan kaum muslimin, tidak serta merta menjadi alasan yang membolehkan ta'jil zakat fitrah. Sehingga ia menjadi satu-sat unya solusi yang mesti ditempuh. Namun, ada solusi yang lain yang juga merupakan rekomendasi dari tulisan singkat ini. Yaitu dengan menggencarkan anjuran kepada masyarakat yang berada (memiliki kelapangan harta), untuk lebih memaksimalkan infak dan sedekah yang bersifat tathawwu' (sunah) yang ditujukan kepada saudara-saudara kita kaum muslimin yang membutuhkan di masa-masa yang sulit seperti hari ini, di masa wabah covid-19. 


\section{DAFTAR PUSTAKA}

Al-Asy'ats, Sulaiman. (1997). Sunan Abi Daud, Juz 2. Beirut: Dar Ibnu Hazm.

Al-Bukhari, Muhammad bin Ismail. (1400H). al-Jami' al-Shahih, Juz. 1. Kairo: al-Mat'ba'ah al-Salafiyah.

Al-Daraquthni, Ali bin Umar. (2004). Sunan al-Daraquthni, Juz 3. Beirut: Muassasah al-Risalah.

Al-Fauzan, Shalih. (2009). Al-Mulakhkhas al-Fiqhi, Juz 1. Iskandariah: Dar alAqidah.

Al-Ifta al-Urdun, Yajuzu Ta'jil Zakah bi Syurut, Situs Resmi Ifta Yordania, http://aliftaa.jo/Question. aspx?QuestionId=2974.

Al-Kasani. (1986). Badāi' al-Sanāi' fì Tartib al-Syarāi', Juz 2. Beirut: Dar Kutub Ilmiyah.

Asy-Syirazi. (1992). Al-Muhadzdab fi Fiqh Imam Syafi'i, Juz 1. Damaskus: Dar al-Qalam.

Bin Baz. Hukmu Ta'jil Zakah wa Miqdaruha fil Mal wa Hukmu Ikhrajiha min gairil mal allazi wajabat fihi zakah. Situs Resmi Syekh Bin Baz. https://binbaz.org.sa/fatwas/11229.

Hazm, Ibnu. (1349 H). Al-Muhalla, Juz 6. Mesir: Idarah Al-Tiba'ah AlMuniriyyah.

Iskandar, A., Aqbar, K. (2019). Kedudukan Ilmu Ekonomi Islam di Antara Ilmu Ekonomi dan Fikih Muamalah: Analisis Problematika Epistemologis. NUKHBATUL 'ULUM: Jurnal Bidang Kajian Islam, Vol. 5, No. 2, h. 88105.

Islam Web.net. Hukmu Ikhraj Ba'dhi Zakah Qabla Hulul Haul. Situs Resmi Islam Web. https://www.islamweb.net/ar/fatwa/113457.

Qudamah, Ibnu. (1997). Al-Mugni, Juz 4. Riyadh: Dar Alam Kutub.

Rusyd, Ibnu. (1995). Bidayah al-Mujtahid wa Nihayah al-Muqtasid, Juz 2. Beirut: Dar Ibnu Hazm. 